\title{
What is Right with the First Year Disadvantaged Students? Towards a Strength Based Perspective in Resolving Poor Academic Achievement in Science and Technology
}

\author{
Duduzile Rosemary Mkhize
}

University of Johannesburg, South Africa

Copyright $(2016$ by authors, all rights reserved. Authors agree that this article remains permanently open access under the terms of the Creative Commons Attribution License 4.0 International License

\begin{abstract}
The challenge facing South Africa's higher education is the poor academic performance of the disadvantaged university students. This leads to a low number of graduates. This is particularly prevalent in the field of science, engineering and technology. Research addressing this problem utilizes deficit models, which focus on what is lacking among students. This paper will argue for a strength based model in tackling the poor performance of first year students. The strength based model has its roots from positive psychology which seeks to focus on what is right, rather than what is wrong. Hence the paper will discuss the strengths the first year students possess. These are malleable self-identity and cognitive growth resulting from their developmental stage, their schoolhouse giftedness exhibited by their high school superior academic performance. And finally their positive coping styles from findings of research on coping styles of adolescents from different countries. The paper argues that these strengths can be utilised as the stepping stones to enhance achievement. The paper concludes by proposing for research that pays more attention and value the strengths the disadvantaged students have, as a strategy to resolve low academic achievement of the disadvantaged youth who enters university.
\end{abstract}

Keywords University Disadvantaged Students, Cognitive Growth, Malleable Self-Identity, Positive Coping Styles, Schoolhouse Giftedness

\section{Background}

The current problem in South African universities is "the appalling dropout rates, and worryingly low throughput rates" [42, p.611]. The situation is particularly bad in the fields of science and technology. These fields have had a long history of lack of access as lamented by the Ministry of Education in the 1995 White Paper on Education and Training, which was promulgated shortly after the first democratic election in South Africa.

"Access to technological and professional careers requiring a strong basis in mathematics and science is denied to all but a fraction of the age cohort, largely because of the chronic inadequacy of teaching in these subjects" [9,p.17].

The White Paper highlighted the challenge of access in science and technology for the disadvantaged majority because of the legacy of apartheid education. Twenty years later, the most disadvantaged youth are able to access science and technology studies at the universities, but this has not translated to success.

Educational research to address the problem has proliferated. However, this is based on a deficit model, that is, what is lacking. This paper will argue for a positive perspective of the problem which does not view students as lacking, but as having some strength which can be utilized as stepping stones for their success.

\section{Literature on the Factors for Low Academic Achievement}

Research in education identifies several students' deficits to be the factors for their poor academic performance at the universities. For example, the mixed method study by Eiselen and Geyser [11, p. 119] found seven broad categories of deficits underpinning poor performance and hence high attrition or dropout rates of disadvantaged students from the universities.

1. Poor academic results prior to entering the university

2. Biographical variables such as age, race and gender

3. Financial and family problems

4. Lack of clear career goals

5 .Inefficient study skills

6. Institutional variables such as instructor behavior and

7. Poor social integration. 


\section{Poor academic results prior to entering the university}

Entrance in science and engineering studies at the South African Universities is based on stringent entry requirements. For example, students must have had an above average pass in mathematics, science and English However, there have been programs called foundation programs which gives students with poor academic results prior entering university [30] [28]. This paper is focusing on students with good academic results prior entering university which seem to poor predictors of academic performance at the university. Mashige et al [28] also found a weak correlation between the scores in matric and the academic performance among the first year students.

\section{Biographical variables such as age, race and gender}

The majority of Black learners in science and technology are the ones with high failure rates.

\section{Financial and family problems}

The majority of Blacks in South Africa are still in living in abject poverty despite the political freedom enjoyed by the country. This means students from such families may have high cognitive ability that gains them entry to science and engineering studies, but will lack financial support that will enable them to pursue their studies effectively. For example, studying on an empty stomach cannot yield positive results.

\section{Lack of clear career goals}

Career guidance for high school learners from families with professional parents comes naturally. These parents usually note at early stage the personalities of their offspring and hence assist them to choose their careers accordingly. This is not the case with semi illiterate parents. Therefore, kids from these families end up in careers that they may not be well suited even though they are in general bright kids. Therefore, they fail not because they lack ability, but because their personalities are not suited for certain careers.

\section{Inefficient study skills}

Transition from high school to university requires a change of study skills. Once more, the poor students suffer as their parents are not able to guide them. Most of the disadvantaged students are the first generation in their families to study at the universities.

\section{Institutional variables such as instructor behavior and}

Universities assume that students are prepared for the university life style, as stated above most disadvantaged students are not prepared.

\section{Poor social integration}

Almost all the factors cited culminate to poor social integration at the university for the disadvantaged students.

Loji [24] argues that lack of problem solving skills among disadvantaged students in engineering studies, makes it difficult for them to succeed, and hence proposes teaching methods that promote these at the universities. According to $\mathrm{Nel}$ et al [31] lack of problem solving skills is the result of the prevalent general inequalities in the education system for the poor students and well off students. To address this, bridging programs also known as the foundation programs, have been implemented by some universities for engineering and science studies. For example, the Science Foundation program is argued to be a strategy to resolve cognitive difficulties prevalent in the transition of students from school to the university [18]. However, some researchers are skeptical about these programs. "Even though overwhelming evidence is available to suggest that access programmes provide access to university where there was none, participation in academic practice is not necessarily guaranteed" [21].

The above have cited examples of research on the factors leading to poor academic performance of students at the universities. Even though the list of research is not exhaustive, but it is very representative of the South African context. The factors cited are revolve around what students lack. They lack problems solving skills, sufficient study skills, and clear career goals and above all, have no good financial backgrounds.

First year students at the universities does have something positive in view of their developmental phase that endows them with some positive characteristics and strengths.

\section{Malleable Self -identity Formation for Academic Achievement}

The most critical year for students is their first year at the university. What is not emphasized among the factors for success at the university is their development stage, namely, adolescence. Hence, the meeting in 1998 of the Society for Research on Adolescence in San Diego, California had a symposium on the adolescence transition to university where factors unique to this developmental stage were discussed as means of smooth transition [33].

Adolescence as a transitional stage from childhood to adulthood is marked by identity formation [12]. Erikson popularized the identity crisis to signify the difficulties adolescents experience as this stage of the development of a stable identity. Contemporary research on adolescence view identity formation as part of positive youth development [17].

Late adolescents who are entering their first year of university are still going through the process of forming identities [5]. This means self-identity is malleable at this stage and can be easily influenced. There is a variety of contextualized identities, hence some researchers have grouped them into categories [20]. According to Berzonsky et al [5]] self -identities that promote success at the university are informational identities; "information oriented individuals actively seek out, evaluate and use self-relevant information" [5]. Adam et al [1] settings that 
influence self-identities include those in schools and universities. Also, Adams, Ryan and Keating [2] argue that supportive academic environments at the universities are essential for the academic achievement of the first year students.

Another malleable aspect of self-identity is self-belief in the learning context. This is also known as academic self-efficacy. According to Pintrich [32] self-efficacy influences academic achievement. Pintrich states; "students who believe they are able and that they can, are more likely to be motivated in terms of effort, persistence, and behaviour than students who believe they are less able". Also Maddux [26] argues that self-efficacy belief gives an individual the power to control their environment. Bandura [3] describes self-efficacy to be; "not a measure of skills one has but a belief about what one can do under different sets of conditions with whatever skills". Beliefs are influenced by environment and personal experiences. Therefore, schools and universities can impede or promote academic self-efficacy.

Another side-lined strength for the first year youth at the universities is the cognitive growth.

\section{Cognitive Growth of First Year Students}

Research has shown that the youth in the age range of 12 to 20 years' experience dramatic cognitive growth. According to Blackmore and Choudhury [7], the prefrontal cortex becomes more effective in overseeing and managing the integrated functioning of various areas, yielding more complex, flexible, and adaptive thinking. Coleman and Hendry [8] claim that there is improvement in attention, both short and long term memory for adolescents. Harris and Butterworth [19] argue that adolescence is marked by new forms of systematic thinking which includes capacity for abstract thinking. Adding to the above cognitive abilities that come with adolescence, Lefrancois $([22$, p. 488$]$ asserts that adolescents have advanced Meta -cognitive skills and their cognitive self-regulation improves.

Research on significant gains in cognitive development among the adolescents is at odds with the cognitive deficits observed during the first year of university for the disadvantaged late adolescents. Explaining this could be the evidence from fMRI(Functional magnetic resonance imaging) that reveals that adolescents recruit the prefrontal cortex's connections with other brain areas less effectively than adults do as prefrontal cognitive control network still requires fine-tuning on tasks needing restraint and future planning [4]. Hence, they tend to reject a larger delayed reward in favour of a smaller immediate reward [40].
However, this becomes a preference or priority problem or an immature cognitive capability which still need fine-tuning exercise, rather than a cognitive deficit.

One needs to take into cognisance the fact that cognitive development only applies in a particular contexts. However, there is something unique about the disadvantaged students who make it to the university. They are the top achieving minority in their disadvantaged schools. The following section elaborates on this and the associated research.

\section{Schoolhouse Giftedness of the First Year Disadvantaged Engineering Students}

Given the history of intelligence tests which was used to justify discrimination in the South African education system [13], intelligence group tests to determine the readiness of learners for specific levels of classes, have been banned in schools. Therefore, in this country intelligence tests results cannot be used to decide who is cognitively superior and who is cognitively inferior. Consequently, there are no gifted programs or gifted education in the school system. However, academic achievement levels for learners are used in the school system as in Table 1:

Table 1. Levels of Achievement in South African schools

\begin{tabular}{|c|c|c|}
\hline $\begin{array}{c}\text { Achievement } \\
\text { Level }\end{array}$ & Achievement Description & Marks \% \\
\hline 7 & Outstanding achievement & $80-100$ \\
\hline 6 & Meritorious achievement & $70-79$ \\
\hline 5 & Substantial achievement & $60-69$ \\
\hline 4 & Adequate achievement & $50-59$ \\
\hline 3 & Moderate achievement & $40-49$ \\
\hline 2 & Elementary achievement & $30-39$ \\
\hline 1 & Not achieved & $0-29$ \\
\hline
\end{tabular}

As an entry requirement into engineering studies at the universities, students must have achieved in their national senior certificate at least $60 \%$ in both mathematics and science. Some engineering programmes require at least $70 \%$ in both mathematics and physical science. Over and above this, high APS (Admission Point Score) which is the total of achievement levels are required, usually above 32 . In the table above only the top three levels are acceptable into engineering programs at the universities.

The National Senior Certificate for 2013 Report indicates that less than $20 \%$ out of the students who wrote matric over the past four years have passed mathematics with percentage of at least $40 \%$ [10]. The following graph indicates the trend in four years, which is 2010, 2011, 2012 and 2013. 


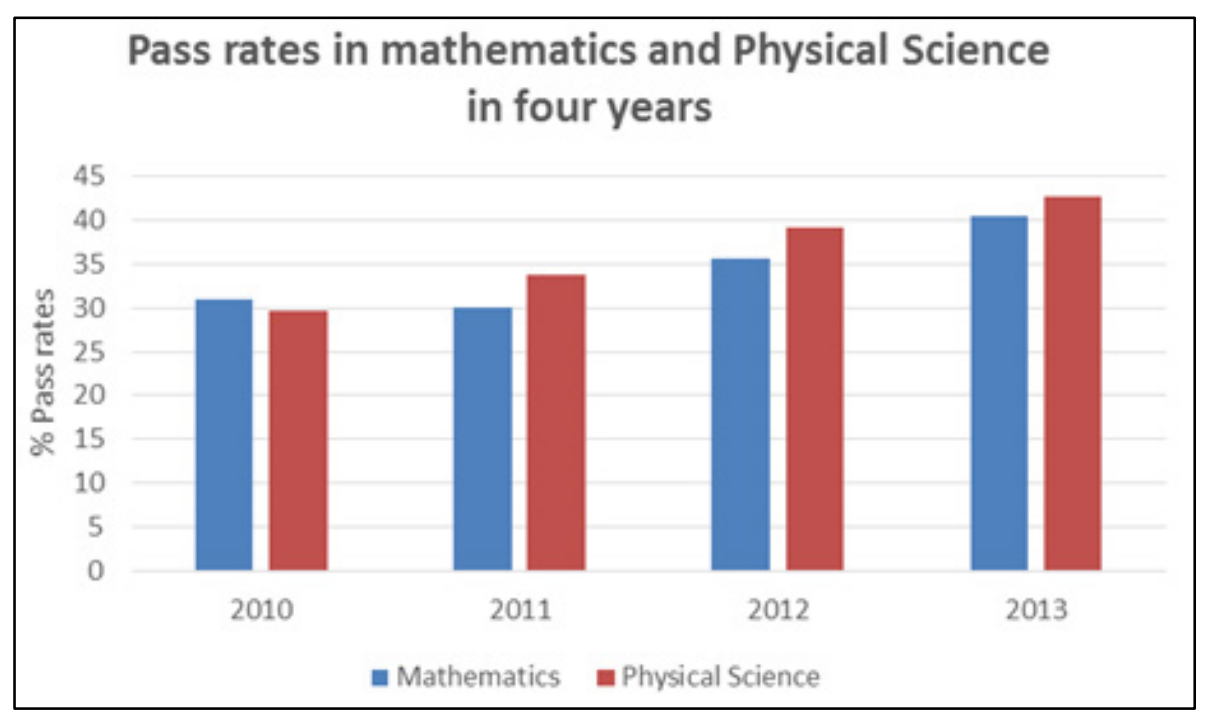

Over a period of four year all students who wrote mathematics and science had a pass rate less than $45 \%$.

Therefore, the students who make it to the first year engineering are above average as they have to have at least $60 \%$ in both mathematics and science. Hence these students are the top achievers in their class! There is literature that states that these students are probably gifted. Renzulli [[4] asserts that giftedness is manifested in two categories. "The first type of giftedness is called high achieving or schoolhouse giftedness, referring to students who are good learners in traditional school achievement" [4]. He defines the other type in terms of the intelligence results obtained by students. Taking Renzulli's definition to apply, the disadvantaged first year engineering students are gifted. According to Mendaglio [29] gifted students' transition to university is not always smooth and is fraught with underachievement. "Gifted students, ironically, confront a different set of psychological demands due to giftedness, which predispose them to academic underachievement" [29].

Also, the perspective that dabs the first year engineering students to be cognitively incapable as a result of having been in disadvantaged schools and impoverished environments, could also be seen a double edged sword . Having survived and came to be among the national top achieving students despite all the hurdles them faced, is testimony that these students are not only high academic achievers, but they are resilient. Research on resilience and coping skills of South African adolescents is discussed in the following section.

\section{Positive Coping Styles of South African Students}

Adolescents are susceptible to stressors associated with challenges they face during this transitional stage. Hence, depression is considered the most serious form of psychopathology in this group [25]. Risk factors implicated in the development of depression include problematic peer relationships [24], negative parental rearing [23] and low socio economic status [14].According to Bhorat and Kanbur [6], there is overwhelming evidence that in the post-apartheid period poverty and inequality have increased.

Adjusting effectively or resilience to such stressors is said to be a result of a positive coping style [34]. Adolescents usually employ two positive coping strategies, these are, active coping and internal coping. Active coping encompasses the coping strategy of active support seeking and internal coping refers to a strategy of reflecting about the problem. Both these coping styles are said to be adaptive coping styles. Withdrawal is said to be a negative coping style and is considered to be maladaptive. More importantly, positive coping styles are associated to academic achievement [27].

An international study of coping strategies by adolescents in 22 countries was conducted by Gelhaar et al [16]

This research found the majority of South African adolescents use active and internal coping in the face of challenges. The following table summarizes the findings in nine countries. 


\begin{tabular}{|c|c|c|c|}
\hline \multicolumn{4}{|c|}{ Table Coping styles in adolescents from nine countries. (Adapted from Seiffege-Krenke,2004:369) } \\
\hline Country & Active Coping & Internal Coping & Withdrawal \\
\hline Germany & 40,4 & 34,8 & 24,7 \\
\hline Switzerland & 38,1 & 40 & 21,9 \\
\hline The Netherlands & 37,9 & 37,9 & 24,1 \\
\hline Croatia & 38 & 38 & 23,9 \\
\hline Portugal & 35,5 & 39,2 & 25,3 \\
\hline Finland & 36,1 & 47,2 & 16,7 \\
\hline Czech Republic & 38,7 & 41,3 & 20 \\
\hline South Africa & 36,9 & 35,4 & 27,7 \\
\hline Hong Kong & 35,4 & 37,5 & 27,1 \\
\hline
\end{tabular}

The above table indicates that $72,3 \%$ of adolescents in South Africa have positive coping styles, that is, either active or internal coping style. Hence, they are capable of surmounting general stressors in their daily lives. This is over and above research that shows that there are approaches that results into positive youth development [39]. Clearly, there is much potential for the South African youth to fully actualise their potential as they adaptive coping styles. This would be viewed as positive youth development.

\section{Conclusions}

Literature discussed on students entering university is based on what is lacking among the first year students. In contrast to the damage construed to be prevalent among the disadvantaged students coming to the university, there are strengths these students have. If used as the basis for research of poor academic performance, these strengths can be utilized as a base for optimal achievement at the university. Highlighting deficits has the potential of inducing the classic learned helplessness [37]. But, identifying strengths can develop optimism [38] among students. Therefore, learned helplessness may be another factor among these students.

The strength based outlook in human functioning is one of the pillars of positive psychology. Its founders stated, "Psychology is not just the study of pathology, weakness, and damage, it is also the study of strength and virtue" [36]. This paper therefore proposes that South Africa desperately needs research on the prevalent underachievement of the disadvantaged engineering students with a paradigm shift from what is lacking to what are the strengths.

\section{REFERENCES}

[1] Adams, G.R. \& Palijan, S. (2004). The identity-education link: six themes in an educational setting that influence adolescent identity development and well-being. In F. Pajares \& T. Urdan (Eds), Educating adolescents: challenges and strategies (pp.237-254). Greenwich, Conn.: Information Age.
[2] Adams, G.R, Ryan, B.A. \& Keating, L. (2000). Family relationships, academic environments, and psychosocial development during the University experience. Journal of Adolescent Research, 15 (1), 99-122

[3] Bandura, A. (1997). Self-efficacy: the exercise of control. New York: W.H. Freeman and Company

[4] Berk, L. E. (2013). Child development. $9^{\text {th }}$ Ed. Boston: Pearson

[5] Berzonsky, M. \& Kuk, L. S. (2000). Identity status, identity processing style and the transition to the university. Journal of Adolescent Research 15(1):81-98

[6] Bhorat, H. \& Kanbur, R. (2006). Poverty and Policy in post-apartheid South Africa. Cape Town; HSRC Press.

[7] Blackmore, S.J. \& Choudhury, S. (2006). Development of the adolescent brain: implications for executive function and social cognition. Journal of Child Psychology and Psychiatry 47: $296-312$

[8] Coleman, J.C. \& Hendry, L.B. (2004). The Nature of Adolescence. 3rd Ed. New York, NY: Routledge.

[9] Department of Education (1995). White Paper on Education. Government Gazette. (Vol.375, No.45621). Pretoria: Republic of South Africa

[10] Department of Basic Education (2013). National Senior Certificate Report for 2013.Pretoria: Education Management System

[11] Eiselen, R. \& Geyser, H. (2003). Factors distinguishing between achievers and at risk students: a qualitative and quantitative synthesis. South African Journal of Higher education 17(2): 118-129

[12] Erikson, E.H. (1968). Identity: Youth and Crisis. London, Faber and Faber Limited.

[13] Fick, M.L. (1929). Intelligence test results of poor white, native (Zulu), colored and Indian school children and the educational and social implications. South African Journal of Science 26: 904-920

[14] Frigeroni, A., Pesenti, S., Molteni, M. \& Battaglia, M. (2001). Depressive symptoms as measured by the CDI in a population of northern Italian children. European Psychiatry 16: 33-37

[15] Garland,M. \& Fitzgeral, M.(1998). Social skills correlates of depressed mood in normal young adolescents. Irish Journal 


\section{of Psychological Medicine 15: 19-21}

[16] Gelhaar, T., Seiffge-Kreneke, I., Bosma, H., Cunha, M., Gillespie, C., Lam, R., Loncaric, D., Macek, P., Steinhausen, H.C., Tam, V., \& Winkler-Metzge, C. (2004). An international perspective on coping behaviour in adolescence. In W. Koops \& H. A. Bosma (Eds), Social Cognition in adolescence ( $p$ p 367-382). East Sussex: Psychology Press

[17] Graf, S.C., Mullis, R.L. \& Mullis, A.K. (2008). Identity Formation of United States American and Asian Indian Adolescents. Adolescence 43(169):57-69

[18] Grussendorf, S., Liebenberg, M., \& Houston, J. (2004). Selection for the science foundation programme (University of Natal): development of a selection instrument. South African Journal of Higher Education 18(1): 265-272

[19] Harris, M. \& Butterworth, G. (2002). Developmental Psychology: a students' handbook. New York, NY: Taylor and Francis Inc.

[20] Hendry, L.B., Leo, B., Mayer, P. \& Kloep, M. (2007). Belonging or Opposing? A grounded Theory Approach to young People's cultural identity in a majority/Minority Societal context. Identity 7(3): 181-204.

[21] Hlalele, D. J. (2010). Do learning skills acquired in the university access programme enhance participation in academic practice? South African Journal of Higher Education 24(1):98-110

[22] Lefrancois, G. R. (2001). An Introduction to Child and Adolescent Development.9th Ed. Belmont, CA: Wadsworth/ Thomson Learning.

[23] Liu, Y. (2003). Parent -child interaction and children's depression: the relationship between parent-child interaction and children's depressive symptoms in Taiwan. Journal of Adolescence 26: 447-457

[24] Loji, K.(2012). Toward teaching methods that develop learning and enhance problems solving skills in engineering students. South African Journal of Higher Education 26 (1):120-135

[25] McPhee, A.R. \& Andrews, J. J. (2006).Risk factors for depressions in early adolescence. Adolescence: 41(163): $435-466$

[26] Maddux, J.E. (2002). Self -efficacy: the power of believing you can. In C.R. Snyder \& S.J. Lopez (Eds), The Handbook of Positive Psychology (pp 277-287). Oxford: Oxford Press Marcia, J.E. (1980). Identity in adolescence. In J. Adelson (Ed), Handbook of Adolescent Psychology (pp159-187). New York: John mCiley \& Sons.

[27] Martin, D., Martin, M., Gibson, S.S. \& Wilkinson, J.(2007). Increasing prosocial behaviour and academic achievement among adolescent African American males. Adolescence, 42(168):689-698
[28] Mashige, K. P., Rampersad, N. \& Venkatas, I. S. (2014). Do national senior certificate results predict first year optometry students' academic performance at university? South African Journal of Higher Education 28(8):550-563

[29] Mendaglio, S. (2013). Gifted students' transition to university. Gifted Education International. 29(1):3-12

[30] Nel, C. \&. Kistner, L. (2009). The National Senior Certificate: Implications for access to higher education. South African Journal of Higher Education 23(5): 953-973

[31] Nel, C, Troskie-de Bruin, C. \& Bitzer , E.(2009). Students' transition from school to university: possibilities for a pre-university intervention. South African Journal of Higher Education 23(5): 974-991

[32] Pintrich, P.R. (2003). A Motivational Science Perspective on the Role of Student Motivation in Learning and Teaching Contexts. Journal of Educational Psychology 95 (4): 667-686

[33] Pratt, M. W. (2000). The transition to University contexts, connections, and consequences. Journal of Adolescent Research 15(1):5-8

[34] Renzulli, J.S. (2012). Re-examining the role of gifted education and talent development for the 21 st century: A four part theoretical approach. Gifted Child Quarterly 56(3):150-159.

[35] Seiff-Krenke, I. (2004). Adaptive and maladaptive coping styles: Does interventions change anything. In W. Koops \& H. A. Bosma (Eds), Social Cognition in adolescence (pp367-382). East Sussex: Psychology Press

[36] Seligman, M.E.P. \& Csikszentmihalyi, M. (2000). Positive Psychology: An Introduction. American Psychologist 55(1): $5-14$

[37] Seligman, E.P. \& Maier, S.F. (1967). Failure to escape traumatic shock. Journal of experimental Psychology 74:1-9

[38] Seligman, M.E.P. (2006). Learned optimism: how to change your mind and your life. New York: Vintage Books

[39] Silbereisen, R.K. \& Lerner, R.M. (2007). Approaches to positive youth development. Los Angeles: Sage Publications

[40] Steinberg, L., Graham, S, O’Brien, L., Woolard, J. Cauffman, E. \& Banich, M. (2009).Age difference in future orientation and delay discounting. Child Development, 80:28-44

[41] Van Eeden, R.; de Beer, M. \& Coetzee, C.H. (2001). Cognitive ability, learning potential, and personality traits as predictors of academic achievement by engineering and other science and technology students. South African Journal of Higher Education 16 (1): 171-179

[42] Yeld, N. (2007). Critical questions? Some responses to issues rose in relation to the national benchmark tests project. South African Journal of Higher education, 21(5),610-616 